\title{
Aquatic habitat modelling: biological validations of IFIM/Phabsim methodology and new perspectives
}

\author{
Y. Souchon ${ }^{(1)}$ and H. Capra ${ }^{(1)}$ \\ Corresponding author: Yves Souchon, souchon@lyon.cemagref.fr
}

\begin{abstract}
Despite IFIM worldwide success, some criticisms have not been sufficiently addressed in the literature: lack of sufficient validation of the relationships between potential available habitat and biomass of fish, particularly in warmwater streams; complexity of habitat modelling; too narrow focus on selected fish species habitat instead of entire riverine ecosystem; complexity and expense of implementation. First, we briefly address the general context of ecological flows methods. Second, we present some successful validations of microhabitat applications at the fish population (Brown trout, Salmo trutta, L. 1758) and community levels. Finally, we present the results of the statistical analysis and modelling of about one hundred Phabsim simulations. The functions of habitat (WUA) versus discharge could be predicted by synthetic hydraulic variables, in particular the Froude and Reynolds numbers. A simplified alternative to Phabsim, named Estimhab opens the way to habitat measurements in a great number of sites, particularly useful to view habitat at entire watershed level.
\end{abstract}

Keys words. - Phabsim, EVHA, Estimhab, biological validation

\section{INTRODUCTION}

The IFIM (Bovee 1978, 1982, 1986; Bovee and Milhous 1978) is one of the dominant worldwide standards for defining ecological instream flows. Only ten years after his publication, this methodology was the most utilised in North America (Reiser et al. 1989; Armour 1991). It is currently one of the most common environmental flow methodologies in use all around the world (see review of Tharme 2003). There are a lot of national adaptations of the core habitat software known as Phabsim. For example Evha in France (Ginot 1995; Ginot et al. 1998), Habiosim in Canada (Dunbar et al. 1997), Rhyhabsim in New Zealand (Jowett 1989).

This high success was inevitably accompanied by several criticisms. Some of them were easy to address, because of the bad comprehension or application of the methodology. Others were more fundamental:

- from the scientific point of view, the central criticism was the lack of Lyon

(1) Cemagref, Quantitative Hydroecology Laboratory, 3 bis quai Chauveau, CP 220, 69336 F- 
sufficient validation of the relationships between potential available habitat and biomass of fish (Orth and Maughan 1982; Mathur et al. 1985; Shirvell 1986; Scott and Shirvell 1987; Orth 1987; Gore et Nestler 1988; Pouilly and Souchon 1995), particularly in warmwater streams (Mathur et al. 1985),

- from an applied point of view, criticisms are related to the complexity of habitat modelling (Barinaga 1996; Hatfield and Bruce 2000; "complex hydrodynamic habitat modelling" Tharme 2003), and to the heaviness of the implementation ("too resource intensive", Tharme 2003). The too narrow focus on selected fish species habitat or life stages instead of entire riverine ecosystem are also criticized.

All these criticisms were very challenging and helped to increase the knowledge for the different compartments of the methodology. As observers of that research field since 20 years, our finding is that there is not enough "eco-" in the developing sciences like ecohydraulics, ecohydrology or ecomorphology. As biologists and ecologists, our research was focused more on biological realism of the habitat modelling. In that paper, we will present a synthesis of some of our already published results.

After a quick overview of the general context of ecological flows methods, with particular attention to IFIM methodology, we discuss successively the following tasks: (i) regional habitat preference curves,

(ii) successful validations of microhabitat applications at fish population (Brown trout, Salmo trutta, L. 1758) and communities levels,

(iii) simplified alternative to Phabsim, supported by statistical analysis of about one hundred Phabsim (Evha(2) for the French version) study sites simulations,

(iiii) observed trends in habitat modelling and perspectives.

\section{IFIM AND PHABSIM IN THE CONTEXT OF METHODOLOGIES FOR PRESCRIBING ENVIRONMENTAL FLOWS}

Recently, Tharme (2003) listed almost 200 instream flow methodologies utilized in 50 countries. These methodologies can be divided into 6 categories as follows: hydrological methodologies $(30 \%)$, hydraulic rating (i.e. wetted perimeter method, $11 \%)$, habitat simulation (28\%), holistic (i.e. environmental flow assessment (EFA) and environmental flow requirements (EFR), 8\%), combination and others (23\%). Two major trends exist. In developed countries of the Northern hemisphere, IFIM (category "habitat simulation") or similar methodologies are massively used. In developing countries or in countries where the environmental legislation is relatively recent (i.e.

(2) http: //www.lyon.cemagref.fr/bea/lhq/logiciel.html 


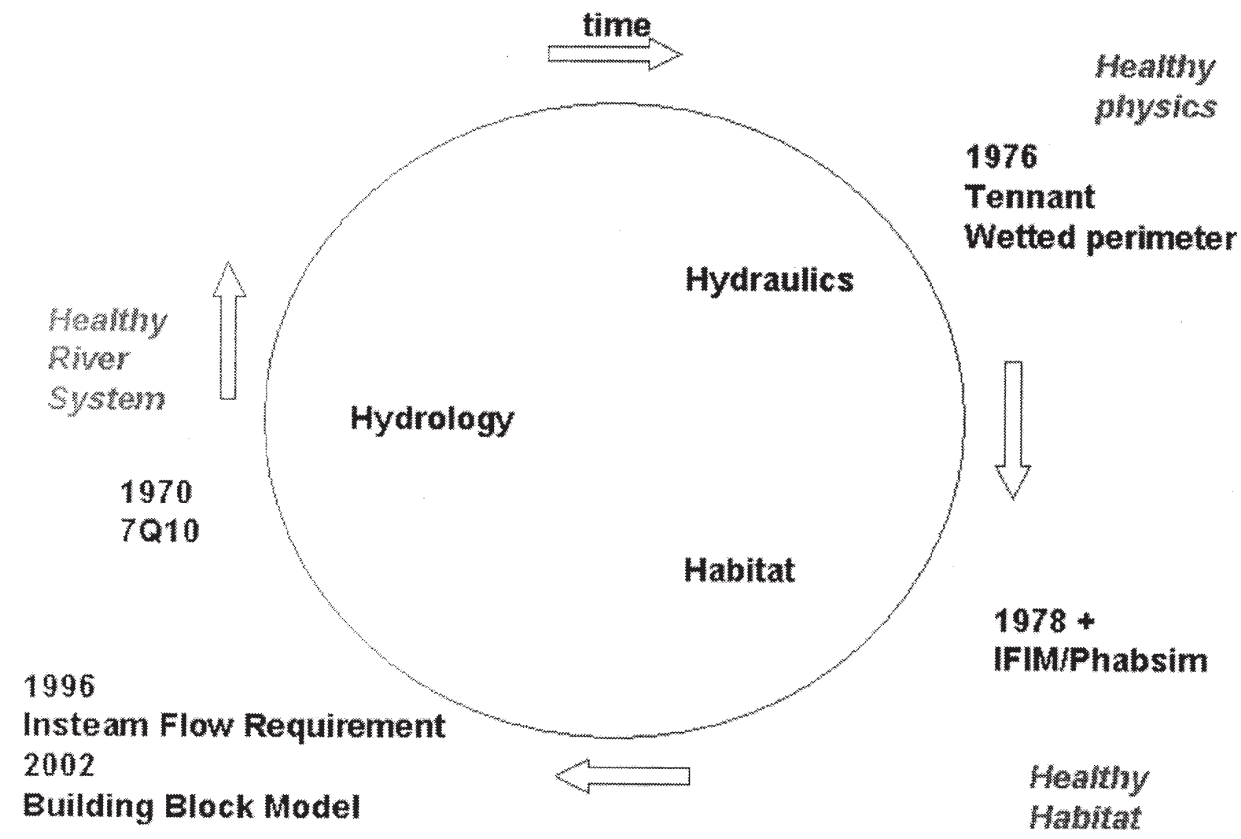

Fig. 1. - "Landscape" of instream flow methodologies. The methodologies for defining environmental flows are composed of 3 fundamental elements: hydrology, hydraulics and habitat. The 200 worldwide existing methods (Tharme 2003) could be associated with one of these elements or a combination of them. The standards are mentioned. In addition a temporal perspective and a "end-product" (in red) is indicated.

South Africa, Australia), there is a trend to use preferentially holistic approaches with different hydrological scenarios and flow requirements for entire riverine ecosystem.

All the methods can be visualized in a scheme composed of 3 basic poles: hydrology, hydraulics and habitat (Figure 1).

In the two previous poles, the ecology is not include as formal models. The objective is more often implicit: as examples, natural flow mimic or conservation of minimum depth on riffles are considered as measures of biological protection. On the contrary, the last pole included explicit habitat models. It is also interesting to project the 3 poles on time and to detect a cyclic pattern, with a strong come back to hydrology in the recent years (Richter et al. 1996).

One of the explanation could be the existence of a certain frustration in front of too narrow applications of Phabsim (obviously not advised by his authors). The come back to easier to understand hydrology, is interpreted as a way to facilitate a more direct identification of the flows re- 
sponsible of the fundamental ecological processes.

\section{REGIONAL HABITAT PREFERENCE CURVES}

Early works in France, in the 1980's, tested brown trout (Salmo trutta, L. 1758) expert preference curves from Bovee (1982) and proposed some amendments, in particular for the substrate preference value (Souchon et al. 1989). This type of model, with preference values between 0 and 1 is also available for Atlantic salmon (Salmo salar, L. 1758) in the standard software EVHA (EValuation of HAbitat) (Ginot 1995; Pouilly et al. 1995; Ginot et al. 1998).

More recently new fish habitat models have emerged, which take into account fish assemblages in order to develop larger scale predictive models (several species for community analysis and large river studies). Regional habitat preference models, based on local velocity, depth and roughness, have been developed for 24 species and their size-classes, commonly found in France and in large European streams (orders 5 to 8) (Lamouroux et al. 1999a). A large data set of 1601 local fish surveys in 6 large streams over an 8-year period was analysed. Sampling surveys were adapted to large streams and considered spatial units of several square meters (between 6 and $90 \mathrm{~m}^{2}$ ) in subunits of stream reaches (for comparable sampling strategies, see Vadas and Orth 1993; Pouilly and
Souchon 1994; Thévenet and Statzner 1999). Multivariate habitat use models were built using Log densities versus different classes of hydraulic variables (see Lamouroux et al. 1998 for details of methodology, particularly for the elimination of effects in multi-sites studies).

This analysis did not transformed the data into suitability indices ranging from 0 to 1 , in order to study multispecies assemblages and to carry out prediction at the community level, estimating either log-densities or frequencies. Although, confidence intervals are provided for fish density in habitat variables classes. Preference models should always include estimates of their uncertainty because habitat models can easily leads to unreliable predictions (Williams 1996).

Most of the fish species and size classes had significant preferences for local habitat conditions which were consistent across the region. Habitat preferences predominant in the region overall were not always observed at any one site, but habitat conditions preferred on average in the region were never actually avoided locally. Regional patterns in habitat preference occur, despite flexibility across sites (Bain 1995; Conklin et al. 1996; Leftwich et al. 1997). In addition, data for a given species/site could be insufficient to reflect preference at any one site.

Therefore, the regional models are attractive tools for large scale, multisite management (Lamouroux et al., 1999a). 


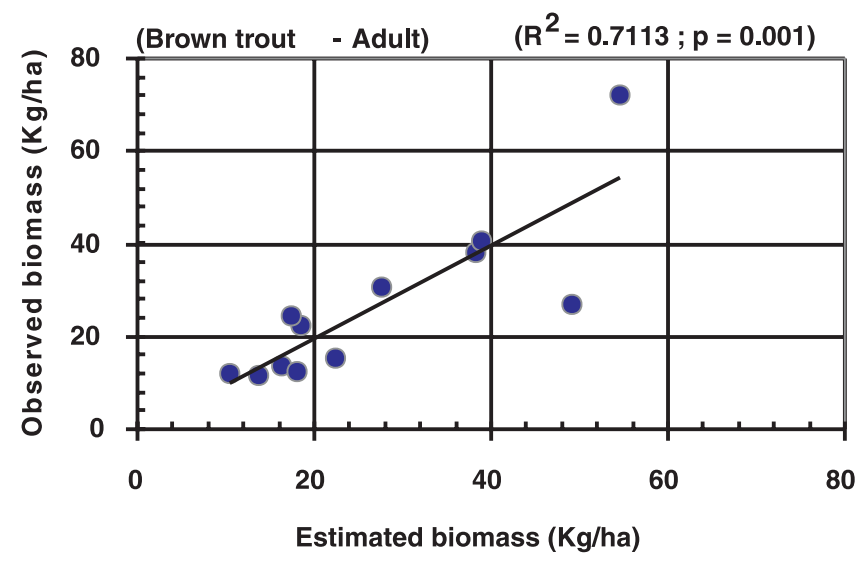

Fig. 2. - Relationships between observed biomass and estimated biomass of adult brown trout (total length $180 \mathrm{~mm}$ ). The estimated biomass is calculated at summer limiting capacity (WUA at mean monthly minimum flow). See text for explanations and Souchon et al. (1989). With permission from authors.

\section{SUCCESSFUL VALIDATIONS OF MICROHABITAT APPLICATIONS AT FISH POPULATION (BROWN TROUT, SALMO TRUTTA) AND AT COMMUNITIES LEVELS}

A complete model validation is a process organized in at least five steps (Grant 1986 cited by Cheslak and Jacobson 1990): "1) examining the capability of the model to address the problem of interest, 2) examining the reasonableness of model structure and individual model mechanisms, 3) examining the qualitative reasonableness of overall model behaviour, 4) examining the quantitative correspondence between overall model behaviour and real system behaviour, and 5) sensitivity analysis of the model".

In this paragraph, we addressed principally the step 4 of the validation.
Several tests have been conducted to tackle this difficult controversial point of the biological realism of the IFIM methodology.

The previous works of Souchon et al. (1989, fig. 2) analysed the links between trout populations interannual average size and limiting carrying capacity calculated by WUA at mean monthly average summer flow (15 reference sites averaged for 3 years). Then Capra et al. (1995) analysed the interannual trout population size variation versus the dynamic of habitat, summarized by selected critical WUA durations. Another step not presented here was the introduction of habitat limitations in dynamic fish population models (see Gouraud et al. this volume). Finally, the adaptation of Phabsim to large rivers and complex fish assemblages has been difficult and were not en- 
tirely satisfactory in the first attempts (Pouilly et al. 1996). We will present thereafter a summary of promising results achieved more recently.

\section{Validation with Brown trout populations averaged through time}

The brown trout population of 15 natural streams without flow regulation and without chemical or thermal limitations has been analysed. In these streams, the brown trout was the unique salmonidae. Souchon et al. (1989) found a very good relationship between WUA at mean monthly average summer flow and adult fish biomass (> $180 \mathrm{~mm}$ in total length) averaged for 3 years of monitoring (fig. 2). These results could certainly be get because no major hydrological event have prevented the population to be at or near full carrying capacity.

Scott and Shirvell (1987) provided one of the first but rather pessimistic synthesis of the tests of validity for the relationships between weighted usable area and fish biomass. They analysed 18 papers: all fish species/ stream types confounded, the majority of studies $(74 \%)$ have found no relationships. However, the results were better, for streams with no flow perturbation (e.g. Stalnaker 1979; Anderson 1984), with strong relationships between WUA and fish biomass for adult brown trout. Several limiting factors could explain the fair or bad relationships observed: longitudinal or lateral fragmentation of habitat, ar- tificial channels, thermal conditions, population dynamic (i.e. population not at carrying capacity the years of observation), intra and interspecific competition, food limitations.

More recently, Jowett (1992) in a multi sites analysis of 59 New Zealand streams concluded to a good agreement between WUA for adult brown trout (length larger than $200 \mathrm{~mm}$ ) at mean annual low flow and trout abundance. Another interesting result was the contribution of the WUA for macroinvertebrates food production at median flow in the regressions.

Even if the relationships between WUA and fish abundance are sometimes obscured, several results demonstrated that habitat is a major determinant of trout abundance. These results are in accordance with ecological theory on the strong effects of local habitat variables, especially hydraulics (Statzner et al. 1988).

\section{Validation with interannual variation of Brown trout population}

The influence of stream discharge (magnitude, intensity, frequency) on the habitat dynamic and on trout population have been tested. IFIM proposes a module dealing specifically with habitat time series. Such specific module is also included in EVHA software. The discharge chronicles are converted to habitat time series. Then seasonal WUA were analysed and 
some over or under threshold for habitat values were defined according to the general knowledge on the effects of floods on salmonids (e.g. discharges equal or superior to two times the mean annual daily flow $+/-2$ SD for the spawning, incubation or emergence period, from november to may, or discharges exceeded $25 \%$ of times for the adult habitat in summer). The details of the methodology of continuous consecutive habitat duration are described by Capra et al. (1995). The biological data are acquired at long term monitoring of three reference salmonids streams. Among different results, the recruitment of $\mathrm{O}_{+}$is limited by the longest period of floods and the adults adapt their number to the carrying capacity limited by the summer flow conditions (Souchon et al. 2002).

These habitat limiting durations are consistent with the results of Nehring and Anderson (1993) for the 2-4 week old fry in 11 study sites in Colorado (13 years monitoring) and with the above mentioned results for the adults. No consistent link have been demonstrated with the 1+ brown trout. Nelson et al. (1992) have had similar results. Our assumption is that this stage is governed at a larger scale than the study sites (3 riffle/pool sequences) and that there exist some downstream migrations of young fish produced in the upper part of the watershed (see also Sabaton et al. this volume). This mechanism seems to be able to compensate some local recruitment gaps. The spatial adjustment obscures certainly the relation- ship between study site habitat, but is very precious in term of population long term sustainability.

The used methodology is useful to analyse the potential critical habitat limitation and to built some discharge scenarios.

A search for higher precision to integrate the biotic relations between fish age classes required to evolve from a rather coarse but useful tool to a more sophisticated approach: there are several ways from classical Leslie matrix (Gouraud et al. this volume) toward Individual Based Models (Bartholow 1993; VanWinkle et al. 1997; Jager et al. 1993, Jager and Tyler 2001, Jager and Rose 2003). All the methodologies share the same need of relevant fish population data to validate the process and to authorize confident predictions.

\section{Validation at complex fish community level}

New developments concerned habitat evaluation at the reach level for complex fish assemblages. They are based on hydraulic statistical models (Lamouroux et al. 1992, 1995) coupled with local multivariate fish habitat models described above. The hydraulic statistical models are tools that predict the frequency distribution of velocity or depth in a stream reach with a simplification of the physical measurements. The relative abundance of fish species (as "community structure indices", see Minns et al. 1996 for discussion) or species 
traits (i.e. reproductive, trophic, morphological) are predicted (Lamouroux et al. 1999b). The predictions have been validated for low flow conditions (low flow corresponding to the ever exceeded value $80 \%$ of time in the classified flows chronicle) with observations within eleven reaches of Rhône river (Lamouroux et al. 1999b). In addition, the "community structure indices" are linked to simple physical descriptors of the reach (Froude and Reynolds numbers).

Mathur et al. (1985) criticized the lack of investigation with warmwater fish. Bowen et al. (1998) described the numerous difficulties in large rivers due to high number of species and poor general knowledge of habitat requirement. The works of Lamouroux et al. (1999b) were the first large scale validations for rivers, because of a long term tradition of local research teams to study the fish communities in large river (Rhône), ending to the building of an exceptional data set accumulated over the long-term (up to 13 years).

These results open the way to a better study of the sensitivity of large rivers to the regulation of flow. The fish habitat requirements are available for a majority of European species. Nevertheless, the application to other aquatic fauna is conceivable, by the means of the ecological traits (Lamouroux et al. 2002).
Simplified alternative to Phabsim, supported by statistical analysis of about one hundred Phabsim (Evha for the French version) study sites simulations

Lamouroux et al. (1995, 1998) demonstrated that hydraulics variables distributions like velocity or depth can be derived from reach values of hydraulic geometry. In the logical extension of these works, the idea of similar results with the common outputs of Phabsim modelling (i.e. the curves WUA as functions of discharge) was tested.

Two separate series of data were tested: 58 French stream reaches dominated by brown trout (Lamouroux and Capra 2002) and 28 streams belonging to the barbel zone' (Lamouroux and Souchon, 2002).

The outputs of instream habitat models (habitat values for three trout life stages and five other species) are predictable from average characteristics of reaches (discharge, depth, width and bed particle size).

As for trout populations, habitat values for fish habitat guilds were strongly related to average, dimensionless characteristics of reaches. The Reynolds number of reaches, equivalent to a discharge per width unit, reflected most of the dischargedependent changes in habitat values (within reaches). In particular, habitat values of species preferring bank (respectively midstream) microhabitats decreased (respectively increased) with increasing Reynolds number. The Froude number at median dis- 
charge was the major predictor of reach-dependent but discharge-independent variations in habitat values. Habitat values of species preferring riffle versus pool or bank microhabitats were higher in reaches with high Froude numbers.

These parameters could be derived from equations of hydraulic geometry of streams. Lamouroux (2002) proposed a simplified alternative to Phabsim, named Estimhab, using these physical properties ${ }^{(3)}$. This simplified methodology opens the way to habitat measurements for a great number of sites. This possibility is useful to view habitat at entire watershed level.

Few studies have broached this theme in the literature. The majority of papers treated one or few study sites. However, Herricks (1985), Orth and Leonard (1990), Jowett (1998) and Hatfield and Bruce (2000) pleaded for some form of generalization of habitat sensitivity at multi sites or watershed level. The last authors provided some interesting ways to link fixed habitat value (maximum or summer characteristics) to median average annual flow or Froude number. The new described models offer more dynamic views of the habitat sensitivity versus discharge in a broad variety of steams and communities. We think with Hatfield and Bruce (2000) that this simplified way to analyse the habitat sensitivity could (1) help managers and project

(3) http: //www.lyon.cemagref.fr/bea/lhq/logiciel.html proponents to conduct preliminary assessments of proposed water-use development projects, (2) optimise research efforts for instream flow studies and experiments, and (3) set experimental boundaries for adaptive management of stream flow (Castleberry et al., 1996).

It could also help to conduct biological validation studies at multiple sites, which is always a current concern in habitat modelling research.

\section{OBSERVED TRENDS IN HABITAT MODELLING AND PERSPECTIVES}

Among the heavy tendencies noticeable at the ecohydraulics symposiums at Trondheim (1994) and Québec (Leclerc et al. 1996), was the increasing complexity of hydraulic models coupled to biology, going 2Dor 3D- modelling (Figure 3a). In the same time great progress have been done to acquire field data with ADCL (Acoustic Dopler Current Profiler), Laser measurements, GPS (Global Positioning Systems). For the details of these new technologies used to describe the physics of streams see Hardy (1998). In parallel, a majority of biologists have pleaded for increasing the number and the precisions of variables in habitat model with the description of the focal nose fish velocity or the habitat use pattern between night and day (Sempeski and Gaudin 1995, Roussel and Bardonnet, 1996) (Figure $3 \mathrm{~b}$ ). The dominant tendency is to develop local habitat models. Modellers developed time and habitat 
Habitat modelling trends

\section{Physical component}

Hydraulic models
$1 \mathrm{D}$
$1,5 \mathrm{D}$
$2 \mathrm{D}, \mathrm{n} \mathrm{D}$

Statistical

Fig. 3a. - Habitat modelling trends. Hydraulics.

\section{Habitat modelling trends}

\section{Biological component}

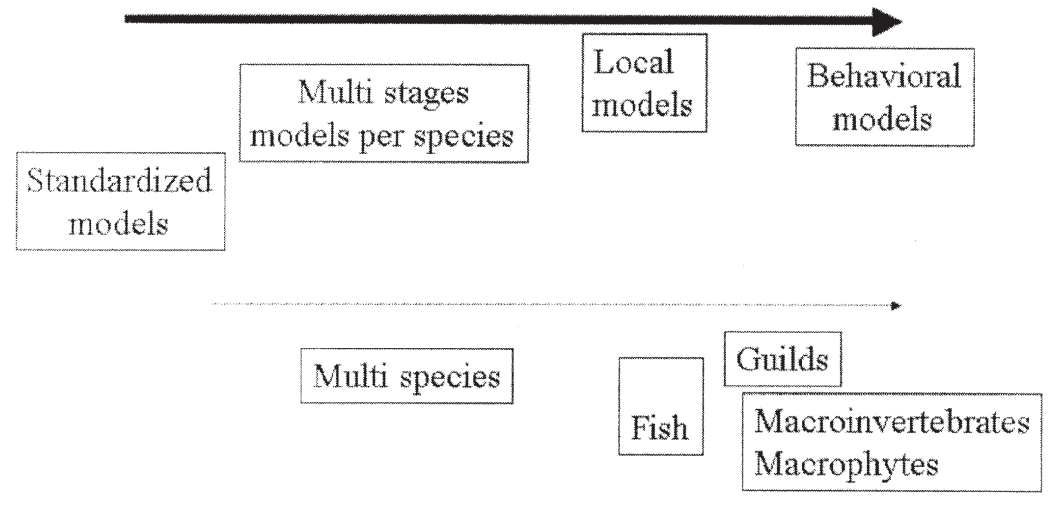

Fig. 3b. - Habitat modelling trends. Fish biology. 
Habitat modeling trends

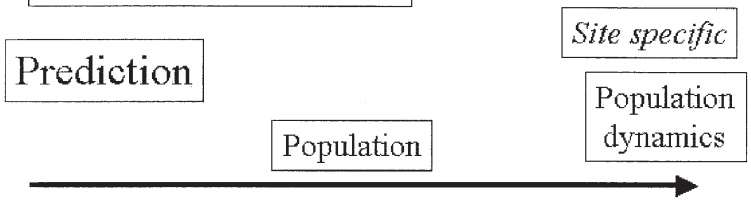

Habitat

Potential

$=\mathrm{f}(\mathrm{Q})$

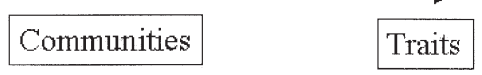

Multi-sites assessment

Fig. 3c. - Habitat modelling trends. Nature of predictions.

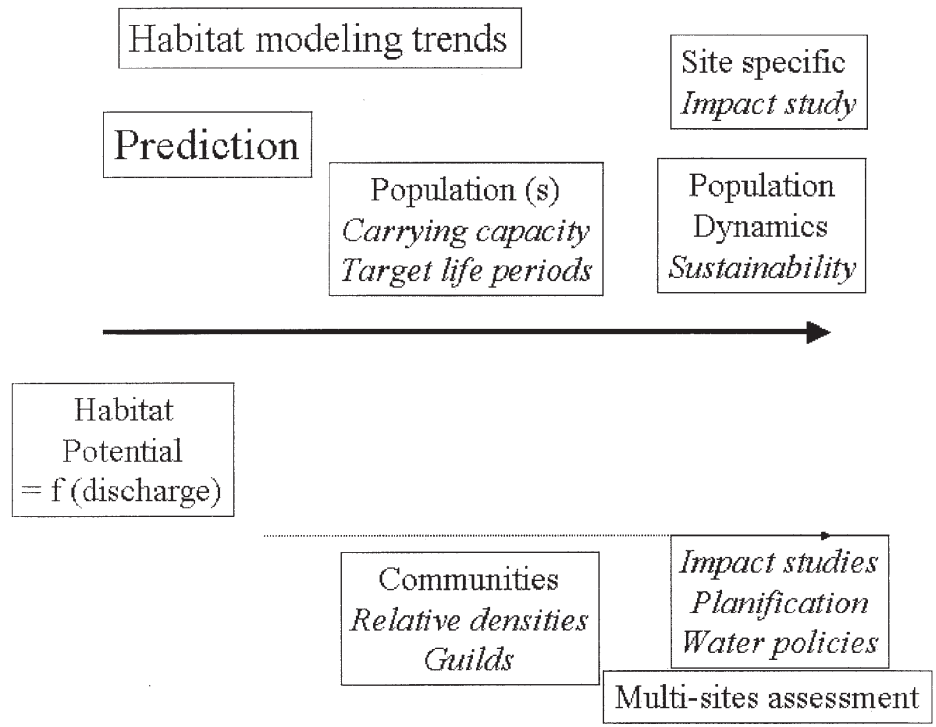

Fig. 3d. - Habitat modelling trends. Applied domains: detailed site impact studies versus large scale habitat evaluation. 
dependant population models, the Individual based models (IBM) being the more detailed, including a great number of parameters (Jager et al. 1993; VanWinkle et al. 1997 ; Jager and Rose 2003). One of the paradox of these different developments is that the biological validation of habitat model predictions remains critical (EPRI 1999 "the lack of an established conceptual framework for IBMs to provide a set of design approaches to make models realistic and accurate", Jager and Rose 2003). In addition, some authors regret the lack of friendly software for IBMs to reduce their cost and make it easier to observe, test, and demonstrate the models (EPRI 1999).

Beside these heavy tendencies, we have explored others ways and proposed numerous habitat models for species and stages or for habitat guilds. We also showed the way to the simplification of physical data acquisition and modelling and proposed an alternative to the costly and laborious process of standard physical modelling (especially for biologists!). We also thought that the economy of time in that process could be better utilised in a more holistic analysis of the general context of the stream and its watershed.

Face to this diversity of methodologies, it seems necessary to draw a typology of the different options (Figures $3 \mathrm{c}$ and $3 \mathrm{~d}$ ). It is very important to understand the "end product of each option", in terms of biological items predicted: depending of the objectives, some would only analyse the habitat sensitivity to flow modifications, other ones a target population, others the long term sustainability of one particular population. Complementary, some would get an overview of the regional habitat sensitivity at a watershed level or test ecological mechanisms with a multi sites sampling designs (Peters 1991). The habitat guilds or traits appeared very promising to study by analogy (proportion of species with particular properties) ecosystems where it is too costly or too time consuming to develop local habitat model (Lamouroux and Souchon 2002; Lamouroux et al. 2002).

At least, at the Cap Town Ecohydraulics symposium (2002), we could notice the renewed success for holistic methodologies (Tharme 2003), centred on hydrology. This way is chosen particularly by the countries that have not experienced microhabitat modelling for a long time.

\section{CONCLUSION}

For almost 25 years, IFIM has stimulated lots of research and new developments. Its quick success was accompanied by several criticisms. A lot of them could be quickly answered or set aside, others have led to improvements in microhabitat modelling (e.g., confidence interval for preference curves, fish assemblages, significance at fish population or communities). Even if methodologies must still be improved, we all have 
the responsibility to stress that the physical habitat, particularly the hydromorphological variables (Statzner et al. 1988), is a fundamental component of healthy streams in agreement with up to date ecological theories: the most severe perturbations of aquatic ecosystems are due to habitat destruction or perturbation (Niemi et al. 1990, NRC 1992).

The majority of the methodological developments are concentrated on complex hydraulic modelling (i.e. 2D, $3 \mathrm{D})$ or behavioural biology (i.e. local, night and day preference curves...), with incorporation in individual-based models. We have explored another way, with the idea to simplify the physical data processing and to offer the possibility of multi sites assessment.

The possibilities for habitat evaluation has increased considerably in these 25 years. The remaining difficulties for agencies or proponents of projects is perhaps to make the right choice. Prior to any negotiation, the objectives have to be clearly defined and accepted. Too often the criticisms addressed to the methodologies are indirectly criticisms of the objectives used in the negotiation.

The numerous scientific questions on the biological realism of microhabitat modelling pointed out the necessity of improving the knowledge of population or community dynamics, particularly in relation to physical habitat. This signifies that sufficient empirical data on living aquatic biota could be acquired on several hydrologic cycles (i.e. long term physical/biological data research sites).

\section{REFERENCES}

Anderson, R.M. 1984. Fish flow investigations. Pages: 1-25 in J.R. Ruch (ed.) Stream fisheries investigations. Colorado Division of Wildlife, Fort Collins, Colorado USA.

Armour, C.I. 1991. Evaluation of the instream flow incremental methodology by U.S. fish and wildlife service field users. Fisheries, 16: 36-43.

Bain, M.B. 1995. Habitat at the local scale: Multivariate patterns for stream fishes. Bulletin Français de la Pêche et de la Pisciculture, 337: 165-177.

Barinaga, M. 1996. A recipe for river recovery? Science, 273: 30-32.

Bartholow, J.M., J.L. Laake, C.B Stalnaker, and S.C. Williamson 1993. A salmonid population model with emphasis on habitat limitations. Rivers, 4: 265-279.

Bovee, K.D. 1978. General management concepts. The incremental method of assessing habitat potential for coolwater species, with management implications. American Fisheries Society Special Publication, 11: 340-346.

Bovee, K.D. 1982. A guide to stream habitat analysis using the instream flow incremental methodology. Instream Flow Information Paper No. 12. U.S. Fish and Wildlife Service. Fort Collins, Colorado USA.

Bovee, K.D. 1986. Development and evaluation of habitat suitability criteria for use in the instream flow incremental methodology. Instream Flow Information Paper, Rep. No. 21 FWS/OBS $86 / 7$, Fish and Wildlife Service, Office of Biological Service, Ft Collins, Colorado USA.

Bovee, K.D., and R.T. Milhous 1978. Hydraulic simulation in instream flow 
studies: theory and techniques. Instream Flow Information Paper $n^{\circ} 5$, Rep. No. FWS/OBS 78/33, U.S. Department of commerce, National Technical Information Service, Colorado, USA.

Capra, H., P. Breil, and Y. Souchon 1995. $A$ new tool to interpret magnitude and duration of fish habitat variations. Regulated Rivers: Research and Management, 10: 281-289.

Castleberry, D.T., J.J. Cech, D.C. Erman, D. Hankin, M. Healey, G.M. Kondolf, M. Mangel, M. Mohr, P.B. Moyle, J. Nielsen, T.P. Speed, and J.G. Williams 1996. Uncertainty and instream flow standards. Fisheries, 21: 20-21.

Cheslak, E.F., and A.S. Jacobson 1990. Integrating the Instream Flow Incremental Methodology with a population response model. Rivers, 1: 264-288.

Conklin, D.J., S.P. Canton, J.W. Chadwick, and W.J. Miller 1996. Habitat suitability curves for selected fish species in the Central Platte River, Nebraska. Rivers, 5: 250-266.

Dunbar, M., A. Gustard, M. Acreman, C.R.N. Elliott 1997. Overseas approaches to setting river flow objectives. Environment Agency Project, Rep. No. W6B (96)4.

Electric Power Research Institute (EPRI), 1999. Software and Conceptual Tools for Individual-based Stream Fish Models: Improving the Cost-Effectiveness and Credibility of Individualbased Approaches for Instream Flow Assessment,TR-114006; Final Report, December 1999.

Ginot, V. 1995. EVHA: Un logiciel d'évaluation de l'habitat du poisson sous Windows. Bulletin Français de la Pêche et de la Pisciculture, 337-338339: 303-308.

Ginot, V., Y. Souchon, H. Capra, P. Breil, and S. Valentin 1998. Logiciel EVHA 2.0. Evaluation de l'habitat physique des poissons en rivière. Guide méthodologique, Cemagref BEA/LHQ et Ministère de l'Aménagement du Territoire et de l'Environnement.

Gore, J.A., and J.M. Nestler 1988. Instream flow studies in perspective. Regulated Rivers: Research and Management, 2: 93-101.

Gouraud, V., C. Sabaton, and H. Capra 2004 , this volume. Role of habitat variability in trout population dynamics. Paper presented at the International IFIM Users' Workshop, Fort Collins, Colorado, USA.

Grant, W.E. 1986. Systems analysis and simulation in wildlife and fisheries sciences. New-York: John Wiley and Son.

Hatfield, T., and J. Bruce 2000. Predicting salmonid habitat - flow relationships for streams from western north America. North American Journal of Fisheries Management, 20: 1005-1015.

Herricks, E.E. 1985. Aquatic habitat analysis as an element of water resources planning and management. Water Science and Technology, 17: 879-890.

Jager, H.I., D.L. Deangelis, M.J. Sale, W.V. Winkle, D.D. Schmoyer, M.J. Sabo, D.J. Orth, and J.A. Lukas 1993. An individual-based model for smallmouth bass reproduction and young-of-year dynamics in streams. Rivers, 4: 91-113.

Jager, H.I., and J.A. Tyler 2001. Discussion on 'Movement rules for individualbased models of stream fish' S.F. Railsback et al. 123 (1999) 73-89. Ecological Modelling, 143: 245-248.

Jager, H. I., and K. A. Rose 2003. Designing Optimal Flow Patterns for Fall Chinook Salmon in a Central Valley, California, River. North American Journal of Fisheries Management, 23: 1-21.

Jowett, I.G. 1989. River Hydraulic and Habitat Simulation, RHYHABSIM Computer Manual. New Zealand Fisheries Miscellaneous Report 49. Ministry of Agriculture and Fisheries, Christchurch. 
Jowett, I.G. 1992. Models of the abundance of large brown trout in New Zealand rivers. North American Journal of Fisheries Management, 12: 417-432.

Jowett, I.G. 1998. Hydraulic geometry of New Zealand rivers and its use as a preliminary method of habitat assessment. Regulated Rivers: Research and Management, 14: 451-466.

Lamouroux, N., B. Statzner, U. Fuchs, F. Kohmann, and U. Schmedtje 1992. An unconventional approach to modeling spatial and temporal variability of local shear stress in stream segments. Water Resources Research, 28: 32513258.

Lamouroux, N., Y. Souchon, and E. Herouin 1995. Predicting velocity distribution in stream reaches. Water $R e$ sources Research, 31: 2367-2375.

Lamouroux, N., H. Capra, and M. Pouilly 1998. Predicting habitat suitability for lotic fish: linking statistical hydraulic models with multivariate habitat use models. Regulated Rivers: Research and Management, 14: 1-11.

Lamouroux, N., H. Capra, M. Pouilly, and Y. Souchon 1999a. Fish habitat preferences in large streams of southern France. Freshwater Biology, 42: 673687.

Lamouroux, N., J.M. Olivier, H. Persat, M. Pouilly, Y. Souchon, and B. Statzner 1999b. Predicting community characteristics from habitat conditions: fluvial fish and hydraulics. Freshwater Biology, 42: 275-299.

Lamouroux, N. 2002. Description of Estimhab. http: // www.lyon.cemagref.fr/bea/lhq/ logiciel.html

Lamouroux, N., and H. Capra 2002. Simple predictions of instream habitat model outputs for target fish populations. Freshwater Biology, 47: 15431556.

Lamouroux, N., and Y. Souchon 2002. Simple predictions of instream habitat model outputs for fish habitat guilds in large streams. Freshwater Biology, 47: 1531-1542.

Lamouroux, N., N.L. Poff, and P.L. Angermeier 2002. Intercontinental convergence of stream fish community traits along geomorphic and hydraulic gradients. Ecology, 83: 1792-1807.

Leclerc, M., H. Capra, S. Valentin, A. Boudreault, and Y. Cote 1996. Proceedings of the second IAHR Symposium on Habitats Hydraulics, Ecohydraulics 2000. 2 vol. Québec, Canada.

Leftwich, K.N., P.L. Angermeier, and C.A. Dolloff 1997. Factors influencing behavior and transferability of habitat models for a benthic stream fish. Transactions of the American Fisheries Society, 126: 725-734.

Mathur, D., W.H. Bason, E.J. Purdy, and C.A. Silver 1985. A critique of the Instream Flow Incremental Methodology. Canadian Journal of Fisheries and Aquatic Sciences, 42: 825-831.

Minns, C.K., J.R.M. Kelso, and R.G. Randall 1996. Detecting the response of fish to habitat alterations in freshwater ecosystems. Canadian Journal of Fisheries and Aquatic Sciences, 53: 403-414.

Nehring, R.B., and R.M. Anderson 1993. Determination of population-limiting critical salmonid habitats in Colorado streams using the physical habitat simulation system. Rivers, 4: 1-19.

Nelson, R.L., W.S. Platts, D.P. Larsen, and S.E. Jensen 1992. Trout distribution and habitat in relation to geology and geomorphology in the North Fork Humboldt river drainage, northeastern Nevada. Transactions of the American Fisheries Society, 121: 405-426.

Niemi, G.J., P. Devore, N. Detenbeck, D. Taylor, A. Lima, J. Pastor, J.D. Yount, and R.J. Naiman 1990. Overview of case studies on recovery of aquatic systems from disturbance. Environmental Management, 14: 571-587. 
NRC, 1992. Restoration of aquatic ecosystems. National Academy Press, Washington, DC USA.

Orth, D.J., and O.E. Maughan 1982. Evaluation of the incremental methodology for recommending instream flow for fishes. Transactions of the American Fisheries Society, 3: 413-445.

Orth, D.J. 1987. Ecological considerations in the development and application of instream flow-habitat models. Regulated Rivers: Research and Management, 1: 171-181.

Orth, D.J., and P.M. Leonard 1990. Comparison of discharge methods and habitat optimization for recommending instream flows to protect fish habitat. Regulated Rivers: Research and Management, 5: 129-138.

Pouilly, M., and Y. Souchon 1994. Simulation de l'habitat physique du barbeau fluviatile (Barbus barbus, L. 1758): choix des modèles biologiques et sensibilité de la réponse. Bulletin Français de la Pêche et de la Pisciculture, 334: 213-215.

Pouilly, M., and Y. Souchon 1995. Méthode des microhabitats: validation et perspectives. Bulletin Français de la Pêche et de la Pisciculture, 337/338/ 339: 329-336.

Pouilly, M., Y. Souchon, Y. Le Coarer, and D. Jouve 1996. Methodology for fish assemblages habitat assessment in large rivers. Application in the Garonne river (France). Volume B, Pages: 324-339 in Leclerc M., H. Capra, S. Valentin A. Boudreault, and Y. Cote (eds.) Second IAHR Symposium on Habitats Hydraulics: Ecohydraulics 2000, Québec, Canada.

Reiser, D.W., T.A. Wesche, and C. Estes 1989. Status of instream flow legislation and practices in North America. Fisheries, 14: 22-29.

Richter, B.D., J.V. Baumgartner, J. Powell, and D.P. Braun 1996. A method for assessing hydrologic alter- ation within ecosystems. Conservation Biology, 10: 1163-1174.

Roussel, J.M., and A. Bardonnet 1996. Changements d'habitat de la truite (Salmo trutta) et du chabot (Cottus gobio) au cours du nycthémère. Approches multivariées à différentes échelles spatiales. Cybium, 20: 43-53.

Sabaton, C., Y. Souchon, J.M. Lascaux, F. Vandewalle, P. Baran, H. Capra, V. Gouraud, F. Lauters, P. Lim, G. Merle, G. Paty. 2004, this volume. A French feedback of IFIM based on habitat and brown trout population time series observations. Paper presented at the International IFIM Users' Workshop, Fort Collins, Colorado, USA.

Shirvell, C.S. 1986. Pitfalls of physical habitat simulation in the instream flow incremental methodology. Canadian technical report of fisheries and aquatic sciences, $n^{\circ} 1460$, Department technical report of fisheries research branch,Prince Rupert, NRC Canada,.

Scott, D., and C.S. Shirvell 1987. A critique of the instream flow incremental methodology and observations on flow determination in New Zealand. Pages: 27-43 in Craig, J.F. and J. B. Kemper (eds.) Regulated Streams: Advances in Ecology. Plenum Press, New York, USA.

Sempeski, P., and P. Gaudin 1995. Sizerelated changes in diel distribution of young grayling (Thymallus thymallus). Canadian Journal of Fisheries and Aquatic Sciences, 52: 1842-1848.

Souchon, Y., F. Trocherie, E. Fragnoud, and C. Lacombe 1989. Les modèles numériques des microhabitats des poissons: application et nouveaux développements. Revue des Sciences de l'Eau, 2: 807-830.

Souchon, Y., H. Andriamahefa, P. Breil, M.B. Albert, H. Capra, and N. Lamouroux 2002. Vers de nouveaux outils pour l'aide à la gestion des hydrosystèmes: couplage des recherches physiques et biologiques 
sur les cours d'eau. Natures Sciences Sociétés, 10: 26-41.

Stalnaker, C.B. 1979. The use of habitat structure preferenda for establishing flow regimes necessary for maintenance of fish habitat. Pages: 321-337 in Ward, J.V. and J. A. Stanford (eds.) The Ecology of Regulated Streams, New York, USA.

Statzner, B., J.A. Gore, and V.H. Resh 1988. Hydraulic stream ecology: observed patterns and potential applications. Journal of the North American Benthological Society, 7: 307-360.

Tharme, R.E. 2003. Global perspective on environmental flow assessment: emerging trends in the development and applications of environmental flow methodologies for rivers. Rivers $R e$ search \& Applications, 19: 397-441.

Thévenet, A., and B. Statzner 1999. Linking fluvial fish community to physi- cal habitat in large woody debris: sampling effort, accuracy and precision. Archiv für Hydrobiologie, 145: 57-77.

Vadas, R.L., and D.J. Orth 1993. A new technique for estimating the abundance and habitat use of stream fishes. Journal of Freshwater Ecology, 8: 305-317.

Van Winkle, W., H.I. Jager, S.F. Railsback, B.D. Holcomb, T.K. Studley, and J.E. Baldrige 1997. Individual based model of sympatric populations of brown and rainbow trout for instream flow assessment: model description, sensitivity analysis, and calibration. Ecological Modelling, 110: 175-207.

Williams, J.G. 1996. Lost in space: minimum confidence intervals for idealized PHABSIM studies. Transactions of the American Fisheries Society, 125: 458465. 
